\title{
РЕАЛІЗАЦІЯ ТЕХНОЛОГІЇ ФОРМУВАННЯ ПОЛІКУЛЬТУРНОЇ КОМПЕТЕНТНОСТІ МАЙБУТНІХ УЧИТЕЛІВ ІНОЗЕМНИХ МОВ
}

\author{
Віолетта Олішевич \\ учитель англійської мови \\ Харківська спеціалізована гімназія № 87 \\ м. Харків, Україна \\ olishevich.v@gmail.com
}

\begin{abstract}
Анотація. У статті представлено теоретичне обгрунтування та шляхи реалізації технології формування полікультурної компетентності майбутніх учителів іноземних мов. Проаналізовано сутність педагогічної технології та надано визначення педагогічної технології в контексті формування полікультурної компетентності майбутніх учителів іноземних мов. Охарактеризовано головні ознаки технології, а саме: концептуальність, системність, ефективність, відтворюваність. Беручи до уваги дослідження вітчизняних та зарубіжних науковців, доведено, що компонентами технології в контексті дослідження є теоретикоконцептуальний, змістовий, процесуальний, рефлексивний. Спроєктовано етапи формування полікультурної компетентності майбутніх учителів іноземних мов: мотиваційно-ціннісний, операційно-пізнавальний, результативно-оцінювальний. На кожному етапі реалізації технології формування полікультурної компетентності майбутніх учителів іноземних мов визначено мету, зміст навчального матеріалу, методи та засоби, які використовуються в освітньому процесі для досягнення поставленої мети.
\end{abstract}

Ключові слова: полікультурна компетентність; майбутні вчителі іноземних мов; діалог культур; контентно-мовне інтегроване навчання.

Постановка проблеми в загальному вигляді. Глобалізація, як цивілізаційна домінанта сучасного розвитку людства, передбачає посилення міжкультурних інтеграційних процесів. Прогрес у галузі засобів комунікації спричинив кризу характерних для попередньої епохи монокультурних моделей розуміння суспільних процесів, зробивши полікультурність ціннісним критерієм суспільного розвитку. Тенденції розвитку сучасного полікультурного суспільства та збереження національних культур різних етнічних груп висвітлено в документі Свропейської комісії «Європейська рамка дій щодо культурної спадщини» (European Framework for Action on Cultural Heritage, 2018), в якому наголошено, що головна відповідальність щодо формування полікультурної компетентності громадян покладена на уряд країн та на заклади вищої освіти. Уряд України долучився до програми Європейського союзу «Креативна Свропа», націленої на розвиток міжкультурного діалогу в громадянському суспільстві. Формування та розвиток полікультурної компетентності студентів закладів вищої освіти є актуальними завданнями сучасної вищої освіти. У контексті ж професійної підготовки майбутніх учителів іноземних мов полікультурна компетентність набуває особливого значення,

Професіоналізм педагога: теоретичні й методичні аспекти. - Вип. 11. - Слов’янськ, 2019. 
Реалізація технології формування полікультурної компетентності майбутніх учителів іноземних мов

оскільки за змістом майже співпадає з міжкультурною мовною компетентністю, що зараховується до ключових елементів фахової підготовки вчителів іноземних мов. Полікультурна компетентність у складі професійної компетентності майбутнього вчителя має розглядатися як динамічне особистісне утворення, яке може формуватися та розвиватися й потребує розробки відповідних технологій його формування в сучасних умовах розвитку суспільства.

Аналіз останніх досліджень і публікацій. У психолого педагогічній літературі висвітлено цілу низку питань щодо визначення змісту та структури самої полікультурної компетентності, обгрунтування технологій, моделей та умов формування полікультурної компетентності. Так, українські вчені С. Сисоєва й I. Соколова (2001) займалися проблемою визначення ролі полікультурної компетентності в професійному становленні майбутнього вчителя. Вивчення питання структури полікультурної компетентності представлено в зарубіжних літературних джерелах, аналіз яких дозволив виявити, що американські вчені (М. Д’Андреа (M. D'Andrea) (2003), А. Міранда (A. Miranda) (2014), Л. Спанірман (L. Spanierman) та інші) виділяють у структурі полікультурної компетентності три компоненти - усвідомлення, знання, уміння, керуючись при цьому загальноприйнятою в зарубіжній педагогічній та психологічній науці структурою компетентності.

Вивченням теоретичних питань розроблення та запровадження педагогічних технологій в освітній процес займаються В. Безпалько, I. Богданова, А. Вербицький, С. Гончаренко, М. Гриньова, І. Дичківська, Т. Дмитренко, О. Дубасенюк, В. Свдокімов, О. Кіяшко, М. Левіна, В. Лозова, О. Пехота， I. Підласий， О. Пометун， I. Прокопенко， I. Руснак， О. Савченко, С. Сисоєва, С. Харченко, С. Яшанова. Українські учені I. Прокопенко та В. Свдокімов (2018), вивчаючи проблему запровадження педагогічних технологій у процес професійної підготовки майбутніх учителів, також наголошують на системності педагогічної технології та на розгляді педагогічної технології як системи науково обгрунтованих дій та взаємодії елементів освітнього процесу, виконання яких забезпечує реалізацію поставлених цілей навчання

Однак, наукові знахідки вищезазначених досліджень не враховують специфіку підготовки майбутніх учителів іноземних мов.

Метою статті є теоретичне обгрунтування та опис реалізації педагогічної технології формування полікультурної компетентності майбутніх учителів іноземних мов.

Методика дослідження. Для досягнення мети дослідження були використані такі теоретичні методи: аналіз наукової літератури 3 метою 


\section{В. ОЛІШЕВИЧ}

Реалізація технології формування полікультурної компетентності майбутніх учителів іноземних мов

визначення та теоретичного обгрунтування технології формування полікультурної компетентності майбутніх учителів іноземних мов; аналіз та узагальнення науково-методичної літератури для окреслення педагогічних умов формування полікультурної компетентності майбутніх учителів іноземної мови; синтез, узагальнення, систематизація для визначення етапів педагогічної технології, а також цілей, змісту, методів та засобів, що застосовуються на кожному з етапів.

Результати дослідження. Проведений аналіз сутності поняття «педагогічна технологія», який висвітлено в наукових працях О. Дубасенюка (2009), В. Свдокімова (2018), І. Прокопенка (2018), С. Сисоєвої (2001) засвідчив, що спільним для всіх визначень у вітчизняній педагогічній науці $є$ їі опис як освітньої системи, яка спрямована на досягнення поставленої мети шляхом виконання певної послідовності навчальних дій та операцій. Вищезазначене свідчить про те, що в українській педагогічній науці розвиток педагогічних технологій відбувався на засадах системного підходу, який є перспективним та науково обгрунтованим.

У контексті нашого дослідження вважаємо, що технологія формування полікультурної компетентності майбутніх учителів $\epsilon$ проєктуванням педагогічної діяльності учасників освітнього процесу щодо відбору навчального контенту, застосування форм та методів професійної мовної підготовки, а також поетапної реалізації процесу формування полікультурної компетентності майбутніх учителів іноземних мов.

Аналіз науково-методичних літературних джерел, в яких висвітлено питання визначення та запровадження педагогічних технологій, дає підстави стверджувати, що переважна кількість українських науковців (О. Дубасенюк, В. Свдокімов, І. Прокопенко, С. Сисоєва та інші) вважають, що для педагогічних технологій характерними є такі ознаки: конц̧ептуальність (будь-яка педагогічна технологія має базуватися на науковій концепції для філософського, психологічного, соціально-педагогічного обгрунтування досягнення очікуваних результатів); системність (педагогічна технологія має бути представлена як система, що реалізується через взаємозв'язок усіх їі компонентів (цілей, змісту, форм, методів, засобів тощо), керованість (реалізація педагогічної технології дозволяє здійснювати управління освітнім процесом та його діагностику на кожному 3 етапів для подальшого варіювання форм, методів та прийомів діяльності); ефрективність (педагогічні технології мають гарантувати досягнення поставленої освітньої мети 3 оптимальними витратами часу та зусиль); відтворюваність (розроблена педагогічна технологія може бути застосована в інших закладах освіти та мати позитивні результати за умови

Професіоналізм педагога: теоретичні й методичні аспекти. - Вип. 11. - Слов’янськ, 2019. 


\section{В. ОЛІШЕВИЧ}

Реалізація технології формування полікультурної компетентності майбутніх учителів іноземних мов

відтворення всіх визначених етапів із застосуванням окреслених форм та методів взаємодії).

I. Прокопенко (2018), описуючи структурні компоненти технології, виділяє такі: концептуальна частина; змістовна частина; процесуальна частина; програмно-методичне забезпечення; професійний компонент. Учений не виділяє в загальній структурі технології рефлексивний компонент, але він наголошує, що рефлексія має застосовуватися на кожному етапі технології для забезпечення зворотного зв’язку та корекції навчального процесу для досягнення поставлених цілей.

Аналіз наукової літератури дозволив визначити компоненти технології формування полікультурної компетентності майбутніх учителів іноземних мов. На нашу думку, до іiі складу входять теоретико-концептуальний, змістовий, процесуальний та рефлексивний. Теоретико-концептуальний компонент реалізується через запровадження системи наукових підходів та принципів формування полікультурної компетентності. Змістовий компонент передбачає визначення мети та змісту полікультурного контенту для формування кожного структурного елемента полікультурної компетентності. Процесуальний компонент тісно корелює зі змістовим і визначає систему методів та засобів, що $\epsilon$ адекватними змісту навчального матеріалу. Ми також розділяємо точку зору вітчизняних науковців (М. Гриньової, О. Дубасенюка, В. Свдокімова, I. Прокопенка, С. Сисоєвої та інші) щодо необхідності виділення рефлексивного компоненту в структурі педагогічної компетентності, який відображає ефективність запровадженої технології через встановлення зворотного зв’язку (Дубасенюк (2009); І. Прокопенко (2018); С. Сисоєва (2001)).

Враховуючи вищезазначену сутність та ознаки педагогічної технології, нами сформульовано умови ефективності технології формування полікультурної компетентності майбутніх учителів іноземних мов: забезпечення інтеграції полікультурного контексту в зміст програмного матеріалу навчальних дисциплін фахової спрямованості; забезпечення взаємозв’язку аудиторної та позааудиторної діяльності в процесі формування полікультурної компетентності майбутніх учителів іноземних мов; використання сучасних педагогічних технологій для опанування майбутніми вчителями загальнокультурних цінностей взаємодії в полікультурному середовищі.

Зміст першої умови полягає в удосконаленні навчального контенту дисциплін фахової підготовки соціокультурним матеріалом із застосуванням дидактичного методу контентно-мовного інтегрованого навчання (Content and Language Integrate Learning (CLIL)). Вітчизняні науковці говорять, що контентно-мовне інтегроване навчання є методом, який позитивно впливає на

(ㄱ ДВНЗ «Донбаський державний педагогічний університет» 


\section{В. ОЛІШЕВИЧ}

Реалізація технології формування полікультурної компетентності майбутніх учителів іноземних мов

формування комунікативної компетентності студентів у тому контексті, в якому вони здобувають загальні знання та вміння (Методика предметно-мовного інтегрованого навчання). Українські дослідники методу контентно-мовного інтегрованого навчання О. Щербакова і С. Нікіфорчук (2017) зауважують, що сферою його застосування $\epsilon$ вивчення немовних предметів іноземною мовою. Однак, зарубіжні науковці (Дж. С. МакДугалд (J. S. McDougald) почасту описують досвід використання контентно-мовного інтегрованого навчання під час вивчення дисциплін іншомовного лінгвістичного циклу в цілому та зокрема як метод формування міжкультурної компетентності. Це говорить про те, що вітчизняні науковці розглядають метод контентно-мовного інтегрованого навчання як засіб міжпредметної інтеграції (Щербакова і Нікіфорчук, 2017). Однак, враховуючи той факт, що вивчення іноземної мови є багатоаспектним, тобто вимагає засвоєння різних мовних аспектів (фонетики, лексики, граматики) не ізольовано, а інтегровано під час здійснення мовленнєвої взаємодії в соціокультурному контексті. Тобто специфіка навчання іноземної мови зумовлює необхідність використання внутрішньопредметної інтеграції, сутність якої полягає у підтримці взаємодії різних аспектів іноземної мови, різних видів мовленнєвої взаємодії та соціокультурного контенту, в якому відбито національно-культурну специфіку країни, мова якої вивчається.

Сутність другої умови - забезпечення взаємозв'язку аудиторної та позааудиторної діяльності в процесі формування полікультурної компетентності майбутніх учителів іноземних мов - полягає в створенні освітнього середовища формування полікультурної компетентності, головними завданнями якого $є$ збереження ідей полікультурності в процесі професійної підготовки вчителя іноземної мови, організація міжкультурної взаємодії всіх учасників освітнього процесу і передусім студентів між собою. У полікультурному освітньому середовищі відображено зміст освіти, методи й засоби навчання, а також форми організації навчального взаємодії у закладах вищої освіти.

Обгрунтовуючи третю педагогічну умову - використання сучасних педагогічних технологій для опанування майбутніми вчителями загальнокультурних цінностей взаємодії в полікультурному середовищі - ми підкреслюємо, що використання інтерактивних технологій забезпечує оптимальний вибір форм, методів і засобів формування полікультурної компетентності.

Ми переконані, що реалізація в освітньому процесі закладу вищої педагогічної освіти вищезазначених умов сприятиме ефективному формуванню полікультурної компетентності майбутніх учителів іноземних мов. Однак, I. Прокопенко зазначає, що ефективність навчання передбачає певну

Професіоналізм педагога: теоретичні й методичні аспекти. - Вип. 11. - Слов’янськ, 2019. 


\section{В. ОЛІШЕВИЧ}

Реалізація технології формування полікультурної компетентності майбутніх учителів іноземних мов

послідовність дій на кожній із стадій (етапів) навчання. Крім того вчений наголошує, що до опису процесу мають бути включені дії кожної стадії та характеристика переходу від однієї стадії до іншої, а також кінцевий результат.

Відповідно до однієї із ключових ознак педагогічної технології системності, яка вимагає визначення етапів процесу формування полікультурної компетентності майбутнього вчителя іноземних мов, із урахуванням усіх компонентів технології, а саме: цілей, змісту, форм, методів і засобів, виникає необхідність обгрунтування структури педагогічної технології для даного дослідження. Питання визначення структури технології в педагогічній науці розробляли I. Вохмяніна, М. Гриньова, В. Свдокімов, С Пєхота, І. Прокопенко, Г. Селевко та інші. Л. Воротняк, досліджуючи проблему формування полікультурної компетентності магістрів у закладах вищої педагогічної освіти, розробила технологію, яка складається 3 мотиваційного, операційнопізнавального, аналітико-корективного та самостійно-творчого етапів.

Виходячи 3 аналізу наукової літератури, а також враховуючи зміст $\mathrm{i}$ структури полікультурної компетентності майбутніх учителів, вважаємо, що технологія формування досліджуваної компетентності має складатися 3 таких етапів: мотиваційно-ціннісний, операційно-пізнавальний $i$ результативнооиінювальний.

Метою мотивоційно-ціннісного етапу є формування потреб, мотивів, інтересів майбутніх учителів іноземних мов до міжкультурної взаємодії в полікультурному середовищі; розвиток ціннісних орієнтацій; формування полікультурних якостей особистості, досвіду міжкультурної взаємодії, усвідомлення соціальних норм і правил поведінки у процесі аудиторної та позааудиторної організації освітньої діяльності.

Беручи до уваги сутність полікультурної компетентності та аналіз іiі структурних компонентів, було встановлено, що іï формування відбувається 3 урахуванням принципу діалогу культур, який визначає соціокультурний контент, що пронизує дисципліни фахової підготовки майбутніх учителів іноземних мов. Враховуючи умови ефективності технології формування полікультурної компетентності майбутніх учителів іноземних мов, а саме забезпечення інтеграції соціокультурного контексту в зміст програмного матеріалу навчальних дисциплін фахової спрямованості через використання методу контентно-мовного інтегрованого навчання, соціокультурний контент насичує інформаційне поле навчальних дисциплін одиницями іншомовної матеріальної культури, елементами духовної і соціальної культури. Головною вимогою розробки навчального заняття із використанням методу контентномовного інтегрованого навчання $\epsilon$ використання автентичних матеріалів, 
Реалізація технології формування полікультурної компетентності майбутніх учителів іноземних мов

представлених у вигляді друкованих текстів, відеоматеріалів, веб-квестів, подкастів та інших інтерактивних матеріалів, які поєднують у собі мотиваційні матеріали, що спонукають студентів до міжкультурної взаємодії, до розвитку загальнокультурних цінностей, а також матеріали для ознайомлення та відпрацювання мовного та мовленнєвого матеріалу, представленого в ситуаціях реальних життєвих умов. Використання автентичних матеріалів створює сприятливе підгрунтя для розуміння картини світу, властивої мові, що вивчається, побудови власної вербальної та невербальної поведінки.

Головною метою операційно-пізнавального етаnу є формування системи полікультурних знань, умінь, навичок, а також досвіду міжкультурної взаємодії через інтеграцію соціокультурного контенту в програму дисциплін фахової підготовки, здійснення безперервної комунікативної практики за принципом діалогу культур.

Як і на мотиваційно-ціннісному етапі, ключовим методом формування складових полікультурної компетентності $\epsilon$ контентно-мовне інтегроване навчання, сутність якого на цьому етапі полягає у структуруванні змісту навчальної дисципліни через інтеграцію в нього тем соціокультурного спрямування. Обов'язковою умовою побудови теми $\epsilon$ наявність у іï структурі двох частин: інформаційної, побудованої на засадах принципу інтеграції змісту навчальної дисципліни 3 соціокультурним контентом, та практичної, яка включає форми, прийоми, методи та засоби, які сприяють засвоєнню інформаційної частини. За умови такої побудови тем у змісті навчальних дисциплін відбувається реалізація когнітивної складової полікультурної компетентності, а саме формування системи полікультурних знань, до складу яких входять загальнокультурні знання 3 країнознавства, історії, педагогіки та психології та специфічні полікультурні знання, пов'язані зі специфікою професійної діяльності вчителя іноземних мов, із урахуванням культурноспецифічних норм, лінгвокраїнознавчих та соціокультурних особливостей іноземної мови.

Реалізація другої та третьої умови технології формування полікультурної компетентності майбутніх учителів іноземних мов відбувається через інтеграцію аудиторної та позааудиторної діяльності. На лекційних заняттях відбувається ознайомлення студентів із значним обсягом полікультурної інформації, для презентації якої застосуються сучасні технічні засоби. На практичному занятті застосовується широкий спектр методів взаємодії студентів та викладача, значна увага приділяється застосуванню інтерактивних вправ, серед них: імітаційні вправи, що відтворюють модель полікультурного середовища, яка визначає модель поведінки людей і стратегії їхньої діяльності в змодельованих ситуаціях;

Професіоналізм педагога: теоретичні й методичні аспекти. - Вип. 11. - Слов'янськ, 2019. 
Реалізація технології формування полікультурної компетентності майбутніх учителів іноземних мов

ділова гра, в ході якої також моделюються певні ситуації взаємодії задля спільного вирішення завдань; дискусія - організована у формі діалогового спілкування взаємодія, у результаті якої студенти набувають досвіду міжкультурного спілкування за умови рівноправної участі кожного студента в обговоренні питань, вирішенні проблем через пропонування розв'язань, а також оцінювання їх адекватності та обгрунтованості.

Позааудиторна робота є логічним продовженням аудиторних занять i планується разом 3 ними. У силу того, що кількість аудиторних годин, відведених на вивчення навчальних дисциплін у закладах вищої освіти, постійно зменшується. Так, постає питання про моделювання комунікативних ситуацій у позааудиторний час. Найпотужнішим засобом для вирішення цієї проблеми можуть бути Інтернет-технологій. Інтернет надає можливість студентам постійного живого спілкування 3 носіями мови 3 іншомовних країн. Таке спілкування може здійснюватися через електронну пошту(e-mail), блог (blog), вікі (wiki), подкаст (podcast), вебквест (web-quest), чат (chat) тощо.

Метою результативно-оцінювального етапу є оцінювання результатів сформованості полікультурної компетентності майбутніх учителів іноземних мов та внесення коректив на основі встановленого зворотного зв'язку.

Сучасні стандарти залишають викладачеві значну свободу у плануванні, організації досягнення і вимірі результатів навчання у форматі компетентностей. Причому не просто свободу у виборі засобів, а свободу варіювання визначених цілей і власне освітніх результатів. Це пов'язано перш за все 3 включенням у зміст поняття «компетентність» особистих якостей студентів. Для оцінювання рівня сформованості полікультурної компетентності таке доповнення змісту поняття «компетентність» має особливе значення. Інструменти вимірювання полікультурної компетентності побудовані на моделях, що містять у своїй структурі ті чи інші якості особистості. Таким чином, сучасні освітні стандарти та існуючі інструменти оцінки забезпечують достатню свободу викладача у виборі методів контролю рівня сформованості полікультурної компетентності.

Яку б форму контролю не обрав викладач, процедура оцінювання починається з обміну інформацією між студентами і викладачем. Залежно від способу отримання даних про рівень сформованості полікультурної компетентності методи контролю поділяють на прямі і непрямі. Прямі методи передбачають отримання даних щодо полікультурної компетентності за допомогою спостереження за поведінкою індивіда. Використання прямих методів допомагає знизити ймовірність впливу студента на результати оцінювання. Непрямі методи оцінювання рівня сформованості полікультурної компетентності спираються не на поведінку студента, а на його відповіді. 


\section{В. ОЛІШЕВИЧ}

Реалізація технології формування полікультурної компетентності майбутніх учителів іноземних мов

Оскільки рівень сформованості компетентності визначається зі слів респондента, вважається, що студент може тим чи іншим чином вплинути на підсумки оцінювання. До найбільш часто використовуваних прямих методів контролю полікультурної компетентності відносять портфоліо, інтерв'ю, спостереження, метод аналізу оповідного щоденника і метод суб'єктивного оцінювання викладачем. Непрямими методами контролю полікультурної компетентності є тестування та анкетування на самооцінку (Гончарова, 2018).

Непрямі методи передбачають заповнення тих чи інших вимірювальних матеріалів, на основі відповідей в яких робиться висновок про рівень сформованості полікультурної компетентності респондента. При цьому аналізуються лише письмові відповіді, найчастіше представлені у формі тестування або анкетування, але не поведінка індивіда в навчальній ситуації. Таким чином, компетентність оцінюється за словами респондента. Широке поширення отримали тести на перевірку рівня сформованості полікультурної компетентності. Іншим непрямим методом контролю полікультурної компетентності є анкетування, в якому студенти повинні самостійно оцінити свій рівень полікультурної компетентності. Наразі полікультурна компетентність традиційно вимірюється за допомогою перекладених (переважно західних) шкал.

У результаті пошуку нових методів контролю полікультурної компетентності довіру викладачів заслужили нові методи оцінювання, наприклад, інтерв'ю та спостереження. І хоча різні види тестування не втрачають свою актуальність, нові методи оцінювання полікультурної компетентності набувають все більшого поширення і визнаються більш надійними. Таким чином, відбувся поступовий перехід від непрямих методів до прямих і змішаним.

Розглянуті вище методи контролю сформованості полікультурної компетентності, використовувані в очній формі навчання, можуть бути реалізовані також у дистанційній формі.

Висновки. Отже, на основі детального теоретичного аналізу педагогічної літератури, встановлено, що педагогічна технологія формування полікультурної компетентності майбутніх учителів іноземних мов реалізується через проєктування етапів педагогічної діяльності учасників освітнього процесу, а саме мотиваційно-ціннісного, операційно-пізнавального та результативнооцінювального. Окреслені умови ефективності педагогічної технології імплементовано на кожному 3 етапів. Ключовим методом формування полікультурної компетентності представлено контентно-мовне інтегроване навчання. Інтеграція мовного і соціокультурного контенту в змісті навчальних дисциплін допомагає розвинути міжнаціональний полілог, здійснюючи який,

Професіоналізм педагога: теоретичні й методичні аспекти. - Вип. 11. - Слов'янськ, 2019. 


\title{
В. ОЛІШЕВИЧ
}

Реалізація технології формування полікультурної компетентності майбутніх учителів іноземних мов

особистість прагне спілкуватися з іншими людьми, усвідомлюючи специфічну для їхньої культури систему пізнання, цінностей, мислення, а також проєктувати набутий новий досвід на власну культурну систему. Напрямками подальших розвідок вважаємо проведення експериментальної перевірки ефективності технології формування полікультурної компетентності майбутніх учителів іноземних мов.

\section{СПИСОК ВИКОРИСТАНИХ ДЖЕРЕЛ}

1. Гончарова, И. С. (2018). Диагностика уровней сформированности поликультурной компетентности будущих менеджеров туризма в образовательном процессе ВУЗа. Актуальные проблемы гуманитарных и естественных наук (Журнал научных публикаций), 11, $92-96$.

2. Дубасенюк, О. А. (Ред.). (2009). Професійна педагогічна освіта: інноваційні технології та методики. Житомир, Україна: Вид-во ЖДУ ім. І. Франка.

3. Методика предметно-мовного інтегрованого навчання (CLIL): світовий досвід. Взято 3 http://elibrary.kubg.edu.ua/id/eprint/2590/1/Rudnik_Y_MNPKL_PP_2013_FLMD_PI.pdf

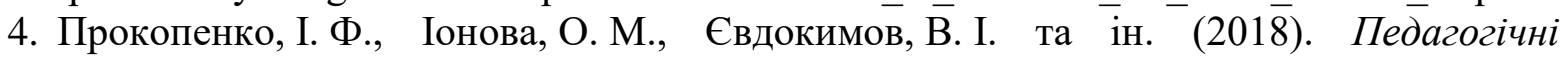
технології в підготовці вчителів: навч. посіб. І. Ф. Прокопенко (Ред.). Харків, Україна: ХНПУ.

5. Сисоєва, С.О., Алексюк, А. М., Воловик, П. М., Кульчицька, О. І. і Сігаєва, Л. С. (2001). Педагогічні технологї у неперервній професійній освіті. С.О. Сисоєва (ред.). Київ, Україна: ВІПОЛ.

6. Щербакова, О. Л., Нікіфорчук, С. С. (2017). Аспекти впровадження предметномовного інтегрованого навчання у ВНЗ. Молодий вчений, 12(52), 490-492.

7. D`Andrea, M., Daniels, J., \& Noonan, M. (2003). New developments in the assessment of multicultural competence: The multicultural awareness-knowledge-skills survey-teachers form. In D. B. Pope-Davis, Ed., Multicultural competencies in counseling and psychology (pp.154-167). Thousand Oaks, CA: Sage Publications, Inc. doi:10.4135/9781452231693.n10

8. European Framework for Action on Cultural Heritage (2018). Взято 3 https://ec.europa.eu/culture/content/european-framework-action-cultural-heritage_en

9. McDougald, J.S. (2017). Language and content in higher education. Latin American Journal of Content and Language Integrated Learning, 10(1), 9-16. doi:10.5294/laclil.2017.10.1.1

10. Miranda, A.H. (2014). Best practices in increasing cross-cultural competency. In Harrison, P. and Thomas, A. (Eds.) Best practices in school psychology: foundations (pp.9-19).

\section{REALISATION OF THE TECHNOLOGY OF DEVELOPING FUTURE FOREIGN LANGUAGE TEACHERS' POLYCULTURAL COMPETENCE}

\author{
Violetta Olishevych \\ English Language Teacher \\ Kharkiv Specialized Gymnasium \#87 \\ Kharkiv, Ukraine \\ olishevich.v@gmail.com
}

\begin{abstract}
The article looks into the theoretical justification of the technology of developing future foreign language teachers' polycultural competence and the ways of its realisation. The relevance of the issue of developing polycultural competence is proved by a number of European and national policy-related documents. The analysis of researches, conducted by Ukrainian and foreign scientists, shows that while studying the concepts "polycultural competence" and "pedagogical
\end{abstract}




\section{В. ОЛІШЕВИЧ}

Реалізація технології формування полікультурної компетентності майбутніх учителів іноземних мов

technology" they emphasize the role of the formation of intercultural competence for future teachers' professional development. The purpose of the article is to depict the realisation of the technology of developing future foreign language teachers' polycultural competence.

The author defines the concept of pedagogical technology in the context of the development of future foreign language teachers' polycultural competence. The paper reveals the main features of the technology: conceptuality, consistency, effectiveness, and reproducibility. Taking into consideration the researches of both Ukrainian and foreign educators, the components of the technology are proved to be theoretical and conceptual, substantive, processual, and reflexive. The author describes in detail the conditions that contribute to the effectiveness of technology realisation. They are the following: the integration of polycultural context with the content of learning materials while studying the professionally-oriented courses; the interconnection of in-class and after-class activities for developing future foreign language teachers' polycultural competence; the implementation of modern pedagogical methods and techniques for developing future teachers' values in polycultural society.

The stages of developing future foreign language teachers' polycultural competence are designed, namely: motivation-valuable, operation-cognitive, and result-assessing. At each stage of developing future foreign language teachers' polycultural competence, the purpose, content of learning material, methods, and means, which are used to achieve the targets, are defined.

Key words: polycultural competence; future foreign language teachers; culture dialogue; content and language integrate learning.

\section{REFERENCES}

1. Goncharova, I. S. (2018). Diagnosis of the levels of development of polycultural competence of future tourism managers in the educational process of universities. Aktualnye problemy gumanytarnyh i estestvennyk nauk (Zhurnal nauchnyh publikatsiy), 11, 92-96.

2. Dubaseniuk, O. A. (Ed.). (2009). Professional Teacher Education: Innovative Technologies and Methods. Zhytomyr, Ukraine: Vyd-vo ZHDU im. I. Franka..

3. Language and Content Integrated Learning (CLIL) Technique: A Global Experience. Retrieved http://elibrary.kubg.edu.ua/id/eprint/2590/1/Rudnik_Y_MNPKL_PP_2013_FLMD_PI.pdf from

4. Prokopenko, I. F., Ionova, O. M., Yevdokymov, V. I. and others. (2018). Pedagogical technologies in teacher training: textbook. I. F. Prokopenko (Ed.). Kharkiv, Ukraine: KhNPU.

5. Sysoieva, S. O., Aleksiuk, A. M., Volovyk, P. M., Kulchytska, O. I. \& Sihaieva, L. E. (2001). Pedagogical technologies in continuing professional education. S. O. Sysoieva (Ed.). Kyiv, Ukraine: VIPOL.

6. Shcherbakova, O. L. \& Nikiforchuk, S. S. (2017). Aspects of introduction of subjectlanguage integrated learning in universities. Molodyi vchenyi, 12(52), 490-492

7. D`Andrea, M., Daniels, J., \& Noonan, M. (2003). New developments in the assessment of multicultural competence: The multicultural awareness-knowledge-skills survey-teachers form. In D. B. Pope-Davis, Ed., Multicultural competencies in counseling and psychology (pp.154-167). Thousand Oaks, CA: Sage Publications, Inc. doi:10.4135/9781452231693.n10

8. European Framework for Action on Cultural Heritage (2018). Retrieved from https://ec.europa.eu/culture/content/european-framework-action-cultural-heritage_en

9. McDougald, J.S. (2017). Language and content in higher education. Latin American Journal of Content and Language Integrated Learning, 10(1), 9-16. doi:10.5294/laclil.2017.10.1.1

10. Miranda, A.H. (2014). Best practices in increasing cross-cultural competency. In Harrison, P. and Thomas, A. (Eds.) Best practices in school psychology: foundations (pp.9-19).

Матеріали надійшли до редакції 15.11.2019 р.

Професіоналізм педагога: теоретичні й методичні аспекти. - Вип. 11. - Слов'янськ, 2019. 